\title{
ПРИНЦИП СВОБОДЫ ГРАЖДАНСКО-ПРАВОВОГО ДОГОВОРА И ЕГО УГОЛОВНО-ПРАВОВАЯ ОХРАНА
}

\begin{abstract}
Аннотация: Действующее российское законодательство предусматривает в качестве одного из важнейших принципов обеспечения гражданских прав физических и юридических лии приниип свободы гражданско-правового договора. Данная статья посвящена исследованию указанного приниипа, законодательно установленных пределов свободы гражданско-правового договора, вопросов применения императивных и диспозитивных норм гражданского права при заключении гражданско-правовых договоров. В статье рассматриваются случаи и механизмы привлечения к уголовной ответственности лии, злоупотребляющих свочми гражданскими правами, нарушающих гражданские права контрагентов, условий, вытекающих из принципа свободы гражданско-правового договора. Методологической основой исследования явилась совокупность общенаучных и специальных методов постижения объективной сочиально-правовой действительности в исследуемой области: методы анализа, синтеза, систематизации и обобщения, формально-логический методы. В статье исследуются и анализируются важнейшие аспекты применения норм российского законодательства о свободе гражданско-правового договора. В проиессе исследования, исходя из анализа правоприменительной практики были выявлены существующие проблемы в рассматриваемой сфере и предложены возможные способы их устранения. Выводы статьи могут быть полезны гражданам, юридическим лицам, а также органам государственной власти и органам местного самоуправления, правоприменительным органам. Abstract: The current Russian legislation provides the principle of a freedom of civil legal contract as one of the key principles of ensuring civil rights of private individuals and legal entities. This article is dedicated to the research of said principle, legal boundaries of the freedom of civil legal agreement, the questions of implementation of imperative and dispositive norms of civil law during signing of legal contracts. The article reviews cases and mechanisms of criminal indictment of individual who have abused their civil rights, violated the civil rights of their business associates, or terms based on the principle of freedom of civil legal agreements. The key aspects of implementation of norms within Russian legislation on freedom civil legal agreements are being researched and analyzed. The conclusions of this article can be useful to citizens, legal entities, as well as the branches of government, local authorities and law enforcement agencies.

Ключевые слова: Свобода гражданско-правового договора, пределы, императивные нормы, диспозитивные нормы, нарушение гражданских прав, злоупотребление правом, уголовная ответственность, наказание, возмещение убытков, уголовно-правовая охрана.
\end{abstract}

Keywords: Freedom of civil legal contract, limitations, imperative norms, dispositive norms, violation of civil rights, abuse of rights, criminal responsibility, punishment, restitution, criminal legal protection.

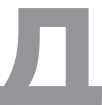

ействующее законодательство России устанавливает, что граждане и юридические лица свободны в установлении своих прав и обязанностей на основе договора и в определении любых не противоречащих законодательству условий договора (ст. 421 Гражданского кодекса Российской Федерации (далее - ГК РФ)). Условия договора определяются по усмотрению сторон, кроме случаев, когда содержание соответствующего условия предписано обязательными для сторон правилами, установленными законом или иными правовыми актами (императивными нормами), действующими в момент его заключения.

В случаях, когда условие договора предусмотрено диспозитивной нормой (то есть нормой, которая применяется постольку, поскольку соглашением сторон не установлено иное), стороны могут своим соглашением исключить ее применение либо установить условие, отличное от предусмотренного в ней ${ }^{1}$.

Норма, определяющая права и обязанности сторон договора, является императивной, если она содержит явно выраженный запрет на установление соглашением сторон условия

\footnotetext{
${ }^{1}$ См.: Дмитриев М.А. Принцип свободы договора (комментарий к статье 421 Гражданского кодекса Российской Федерации) // Мировой судья. - 2011. - № 12. - С. 10-14; Федин В.В. Соотношение принципа свободы труда и права на труд // Lex Russica.- 2004. - № 2. - C. 411435 и др.
}

договора, отличного от предусмотренного этой нормой правила (например, в ней предусмотрено, что такое соглашение ничтожно, запрещено или не допускается, либо указано на право сторон отступить от содержащегося в норме правила только в ту или иную сторону, либо названный запрет иным образом недвусмысленно выражен в тексте нормы).

Вместе с тем из целей законодательного регулирования может следовать, что содержащийся в императивной норме запрет на соглашение сторон об ином может толковаться ограничительно. Например, ст. 29 Федерального закона от 2 декабря 1990 года № 395-1 «О банках и банковской деятельности» установлен запрет на одностороннее изменение кредитной организацией порядка определения процентов по кредитному договору, заключенному с заемщиком-гражданином, при этом указанное не означает, что запрещено такое одностороннее изменение указанного порядка, вследствие которого размер процентов по кредиту уменьшается.

При отсутствии в норме, регулирующей права и обязанности по договору, явно выраженного запрета установить иное, она является императивной, если исходя из целей законодательного регулирования это необходимо для защиты особо значимых охраняемых законом интересов (интересов слабой стороны договора, третьих лиц, публичных интересов и т.д.), недопущения грубого нарушения баланса интересов сторон либо императивность нормы вытекает из существа законодательного регулирования данного вида договора. 
DOI: $10.7256 / 1811-9018.2014 .12 .11940$

При цитировании этой статьи сноска на dоі обязательна

Юридический практикум

При возникновении спора об императивном или диспозитивном характере нормы, регулирующей права и обязанности по договору, суд указывает, каким образом существо законодательного регулирования данного вида договора, необходимость защиты соответствующих особо значимых охраняемых законом интересов или недопущение грубого нарушения баланса интересов сторон предопределяют императивность этой нормы либо пределы ее диспозитивности.

Например, п. 2 ст. 610 ГК РФ предусматривает право каждой из сторон договора аренды, заключенного на неопределенный срок, немотивированно отказаться от договора, предупредив об этом другую сторону в названные в данной норме сроки. Данная норма хотя и не содержит явно выраженного запрета на установление иного соглашением сторон, но из существа законодательного регулирования договора аренды как договора о передаче имущества во временное владение и пользование или во временное пользование (ст. 606 ГК РФ) следует, что стороны такого договора аренды не могут полностью исключить право на отказ от договора, так как в результате этого передача имущества во владение и пользование фактически утратила бы временный характер.

П. 1 ст. 463 ГК РФ, в соответствии с которым покупатель вправе отказаться от исполнения договора купли-продажи, если продавец отказывается передать покупателю проданный товар, не содержит явно выраженного запрета предусмотреть договором иное, например, судебный порядок расторжения договора по названному основанию вместо права на односторонний отказ от его исполнения. Однако договором не может быть полностью устранена возможность его прекращения по инициативе покупателя в ситуации, когда продавец отказывается передать ему проданный товар, поскольку это грубо нарушило бы баланс интересов сторон.

Согласно п. 1 ст. 544 ГК РФ, оплата энергии производится за фактически принятое абонентом количество энергии в соответствии с данными учета энергии, если иное не предусмотрено законом, иными правовыми актами или соглашением сторон договора энергоснабжения (купли-продажи (поставки) энергии). Если плата за единицу поставляемого ресурса является регулируемой, то указанная норма может быть истолкована лишь следующим образом: установление соглашением сторон иного количества энергии, которое оплачивает абонент (потребитель, покупатель), допускается только тогда, когда невозможно определить фактически принятое им количество энергии в соответствии с данными учета, а закон или иные правовые акты не содержат порядка определения такого количества в отсутствие данных учета. Это правило направлено на защиту публичных интересов, обеспечиваемых государственным регулированием тарифов.

В соответствии с п. 2 ст. 421 ГК РФ стороны вправе заключить договор, не предусмотренный законом и иными правовыми актами (непоименованный договор).

При оценке судом того, является ли договор непоименованным, принимается во внимание не его название, а предмет договора, действительное содержание прав и обязанностей сторон, распределение рисков и т.д.

К непоименованным договорам при отсутствии в них признаков смешанного договора (п. 3 ст. 421 ГК РФ) правила об отдельных видах договоров, предусмотренных законом или иными правовыми актами, не применяются. Однако нормы об отдельных видах договоров, предусмотренных законом или иными правовыми актами, могут быть применены к непоименованному договору по аналогии закона в случае сходства отношений и отсутствия их прямого урегулирования соглашением сторон (п. 1 ст. 6 ГК РФ). Применение к непоименованным договорам по аналогии закона императивных норм об отдельных поименованных видах договоров возможно в исключительных случаях, когда исходя из целей законодательного регулирования ограничение свободы договора необходимо для защиты охраняемых законом интересов слабой стороны договора, третьих лиц, публичных интересов или недопущения грубого нарушения баланса интересов сторон. При этом суд должен указать на то, какие соответствующие интересы защищаются применением императивной нормы по аналогии закона² .

В случаях злоупотребления стороны своим правом, вытекающим из условия договора, отличного от диспозитивной нормы или исключающего ее применение, либо злоупотребления своим правом, основанным на императивной норме, суд с учетом характера и последствий допущенного злоупотребления отказывает этой стороне в защите принадлежащего ей права полностью или частично либо применяет иные меры, предусмотренные законом (п. 2 ст. 10 ГК РФ).

В частности, в случае выявления в действиях недобросовестного контрагента признаков злоупотребления - преступления, посягающего на экономические интересы одной из сторон (мошенничество, присвоение или растрата, причинение имущественного ущерба путём обмана или злоупотребления доверием в крупном (особо крупном) размере и т.д.) недобросовестная сторона привлекается к уголовной ответственности по статьям раздела VIII Уголовного кодекса Российской Федерации «Преступления в сфере экономики» (далее - УК РФ).

Например, ст. $159^{4}$ УК РФ предусматривает ответственность за мошенничество, сопряжённое с преднамеренным неисполнением договорных обязательств в сфере предпринимательской деятельности. Данное преступление посягает на принцип свободы гражданско-правового договора, поскольку влечёт неисполнение тех условий и обязательств, которые стороны исходя из данного принципа в договоре предусмотрели.

В качестве частного случая данной уголовно-правовой нормы (специальной уголовно-правовой нормы) выступает норма, установленная в ст. 196 УК РФ, предусматривающая уголовную ответственность за преднамеренное банкротство, то есть совершение руководителем или учредителем (участником) юридического лица либо индивидуальным предпринимателем действий (бездействия), заведомо влекущих неспособность юридического лица или индивидуального предпринимателя в полном объёме удовлетворить требования кредиторов по денежным обязательствам и (или) исполнить обязанность по уплате обязательным платежей, если эти действия (бездействие) причинили крупный ущерб (то есть ущерб на сумму, превышающую 1 млн. 500 тыс. рублей).

Данное деяние также нарушает принцип свободы гражданско-правового договора, поскольку противоречит тем

\footnotetext{
${ }^{2}$ См.: Постановление Пленума Высшего Арбитражного Суда Российской Федерации от 14 марта 2014 г. № 16 «О свободе договора и её пределах» // СПС «КонсультантПлюс».
} 
DOI: $10.7256 / 1811-9018.2014 .12 .11940$

При цитировании этой статьи сноска на доі обязательна

\section{Право и политика $12(180) \cdot 2014$}

целям, для достижения которых соответствующий гражданско-правовой договор был заключён.

При этом в случае выявления признаков вышеуказанных деяний в действиях недобросовестного контрагента последний будет подлежать уголовной ответственности по ст. 196 УК РФ, поскольку в соответствии со ст. 17 УК РФ если преступление предусмотрено общей и специальной нормами, совокупность преступлений отсутствует и уголовная ответственность наступает по специальной норме.

Ст. 160 УК РФ устанавливает уголовную ответственность за присвоение или растрату, то есть хищение чужого имущества, вверенного виновному (например, в случае заключения гражданско-правовых договоров аренды, подряда, комиссии, перевозки, хранения и др. с виновным, в результате которого соответствующее имущество последнему было вверено). Данное преступление также посягает на права добросовестного контрагента (лица, передавшего имущество виновному), вытекающие из принципа свободы договора, предполагающего установлений условий, соответствующих существу императивных и диспозитивных норм гражданского права. Лицо, привлекаемое к уголовной ответственности за уголовно наказуемые нарушения гражданских прав, помимо собственно наказания, предусмотренного УК РФ, обязано в случае заявления пострадавшим требования в гражданском судопроизводстве возместить ущерб, причинённый недобросовестными действиями виновного.

\section{Библиография:}

1. Дмитриев М.А. Принцип свободы договора (комментарий к статье 421 Гражданского кодекса Российской Федерации) // Мировой судья. - 2011. - № 12. - С. 10-14.

2. Федин В.В. Соотношение принципа свободы труда и права на труд // Lex Russica. - 2004. - № 2. - C. 411-435.

3. Ахрамеева О.В. Определение подсудности в делах при оспаривании обязательств по договору, в котором не определено место его исполнения // NB: Вопросы права и политики. - 2013. - 7. - C. 168-176. DOI: 10.7256/2305-9699.2013.7.8939. URL: http://www.e-notabene. ru/lr/article_8939.html

4. А. А. Энгельгардт Основания применения норм об идеальной совокупности преступлений // Право и политика. - 2012. - 2. - С. $282-287$.

5. Иодковский Э.В. Тенденции применения решений Европейского суда по правам человека в гражданском судопроизводстве // Актуальные проблемы российского права. - 2012. - 2. - С. 196-206.

6. К.А. Галин К вопросу о современном содержании принципа свободы договора в законодательстве Германии и России // Журнал зарубежного законодательства и сравнительного правоведения. - 2011. - 5. - С. 134-139.

7. Гончаренко Е.А. Особенности заключения кредитного договора, исполнение которого обеспечено ипотекой // NB: Финансовое право и управление. - 2013. - № 4. - C.37-43. DOI: 10.7256/2306-4234.2013.4.2227. URL: http://e-notabene.ru/flc/article_2227.html

8. Галин К.А. Ограничения принципа свободы договора нормами закона в законодательствах Германии и России // Журнал зарубежного законодательства и сравнительного правоведения. - 2012. - 4. - С. 135-143.

9. Ю.В. Умнова Общественная опасность в процессе уголовного правотворчества и правоприменения // Актуальные проблемы российского права. - 2011. - 2. - С. 208-214.

10. Буюкли В.И. Субъектное измерение функции охраны права // NB: Вопросы права и политики. - 2014. - 1. - C. 1-18. DOI: 10.7256/23059699.2014.1.10157. URL: http://www.e-notabene.ru/lr/article_10157.html

11. Молдованов М.М. Анализ договора банковского вклада как инструмента борьбы с мировым финансово-экономическим кризисом на примере ряда зарубежных государств // NB: Финансовое право и управление. - 2013. - № 1. - C.100-120. DOI: 10.7256/2306-4234.2013.1.569. URL: http://e-notabene.ru/flc/article_569.htm

12. Карчевский Н.В. Основные направления совершенствования уголовного законодательства в контексте социальных тенденций информатизации // NB: Вопросы права и политики. - 2013. - 6. - C. 152 - 196. DOI: 10.7256/2305-9699.2013.6.8317. URL: http://www.e-notabene. $\mathrm{ru} / \mathrm{lr} /$ article_8317.html

13. Токарчук Р.Е. Общественная опасность как общий принцип уголовного права и уголовной ответственности // NB: Вопросы права и политики. - 2012. - 1. - C. 126 - 142. URL: http://www.e-notabene.ru/lr/article_51.html

\section{References (transliterated):}

1. Dmitriev M.A. Printsip svobody dogovora (kommentarii k stat'e 421 Grazhdanskogo kodeksa Rossiiskoi Federatsii) // Mirovoi sud'ya. - 2011. - № 12. - S. 10-14.

2. Fedin V.V. Sootnoshenie printsipa svobody truda i prava na trud // Lex Russica. - 2004. - № 2. - S. 411-435.

3. Akhrameeva O.V. Opredelenie podsudnosti v delakh pri osparivanii obyazatel'stv po dogovoru, $\mathrm{v}$ kotorom ne opredeleno mesto ego ispolneniya // NB: Voprosy prava i politiki. - 2013. - 7. - C. 168-176. DOI: 10.7256/2305-9699.2013.7.8939. URL: http://www.e-notabene.ru/lr/article_8939.html

4. A. A. Engel'gardt Osnovaniya primeneniya norm ob ideal'noi sovokupnosti prestuplenii // Pravo i politika. - 2012. - 2. - C. 282-287.

5. Iodkovskii E.V. Tendentsii primeneniya reshenii Evropeiskogo suda po pravam cheloveka v grazhdanskom sudoproizvodstve // Aktual'nye problemy rossiiskogo prava. - 2012. - 2. - C. 196-206.

6. K.A. Galin K voprosu o sovremennom soderzhanii printsipa svobody dogovora v zakonodatel'stve Germanii i Rossii // Zhurnal zarubezhnogo zakonodatel'stva i sravnitel'nogo pravovedeniya. - 2011. - 5. - C. 134-139.

7. Goncharenko E.A. Osobennosti zaklyucheniya kreditnogo dogovora, ispolnenie kotorogo obespecheno ipotekoi // NB: Finansovoe pravo i upravlenie. - 2013. - № 4. - S.37-43. DOI: 10.7256/2306-4234.2013.4.2227. URL: http://e-notabene.ru/flc/article_2227.html

8. Galin K.A. Ogranicheniya printsipa svobody dogovora normami zakona v zakonodatel'stvakh Germanii i Rossii // Zhurnal zarubezhnogo zakonodatel'stva i sravnitel'nogo pravovedeniya. - 2012. - 4. - C. 135-143.

9. Yu.V. Umnova Obshchestvennaya opasnost' v protsesse ugolovnogo pravotvorchestva i pravoprimeneniya // Aktual'nye problemy rossiiskogo prava. - 2011. - 2. - C. 208-214.

10. Buyukli V.I. Sub" 'ektnoe izmerenie funktsii okhrany prava // NB: Voprosy prava i politiki. - 2014. - 1. - C. 1-18. DOI: 10.7256/23059699.2014.1.10157. URL: http://www.e-notabene.ru/lr/article_10157.html 
DOI: $10.7256 / 1811-9018.2014 .12 .11940$

При цитировании этой статьи сноска на доі обязательна

Юридический практикум

11. Moldovanov M.M. Analiz dogovora bankovskogo vklada kak instrumenta bor'by s mirovym finansovo-ekonomicheskim krizisom na primere ryada zarubezhnykh gosudarstv // NB: Finansovoe pravo i upravlenie. - 2013. - № 1. - S.100-120. DOI: 10.7256/2306-4234.2013.1.569. URL: http://e-notabene.ru/flc/article 569.htm

12. Karchevskii N.V. Osnovnye napravleniya sovershenstvovaniya ugolovnogo zakonodatel'stva v kontekste sotsial'nykh tendentsii informatizatsii // NB: Voprosy prava i politiki. -2013. -6. - C. 152 - 196. DOI: 10.7256/2305-9699.2013.6.8317. URL: http://www.e-notabene.ru/lr/article_8317.html

13. Tokarchuk R.E. Obshchestvennaya opasnost' kak obshchii printsip ugolovnogo prava i ugolovnoi otvetstvennosti // NB: Voprosy prava i politiki. -2012. - 1. - C. 126 - 142. URL: http://www.e-notabene.ru/lr/article_51.html 